\title{
The political economy of comprehensive social policy reform and emergence of a social policy paradigm: the case of Slovakia
}

\author{
Miroslav Beblavý \\ Slovak Governance Institute, Bratislava \\ Institute of Public Policy, Comenius University, Bratislava
}

\section{Introduction}

In many European countries, significant changes in social policy are needed to ensure successful policy outcomes in employment, social inclusion and overall prosperity. However, many governments have been unable to implement the changes due to resistance by special interests as well as broader sections of population. The paper uses the example of Slovakia, which has been able to introduce a comprehensive social policy reform (including pension reform, labour market reform and tax and benefit reform), to study the political economy of such changes and what has enabled the Slovak government to successfully introduce them.

The paper first looks at reasons underlying the need for comprehensive changes in social policy in many European countries. It then describes the reform package adopted in Slovakia and analyses political and other factors that made it possible to design, implement, and sustain a radical change of this sort. In the conclusion, it looks at whether a broader new social policy paradigm can be identified as emerging among the new member states of the European Union.

\section{Social policy reform: why is it needed and why is it a problem}

The issue of social policy reform has been at the forefront of policy debate in Europe for several years now, but it is, if anything, growing more and more important. The previous German Chancellor and social democrat, Gerhard Schröder, routinely called for "radical social policy reform in Europe". (Český rozhlas (2004)) A meeting of European finance ministers in 2005 was presented with a paper entitled "Globalisation and the Reform of European Social Models", which stated in its introduction: "The biggest challenge for the European economy is to become sufficiently flexible so as to avail of the opportunities and surmount the threats [of globalisation... requiring] reforming labour market and social policies..." (Sapir (2005)) These calls for action illustrate the urgency of the problem, but what are its causes and potential solutions?

One of the most concise summaries was recently provided by Giddens (2005). He argues that, despite a variety of approaches, a general thread of all European social models can be defined by: "a developed and interventionist state, as measured in terms of level of GDP taken up by taxation... A robust welfare system, that provides effective social protection, to some considerable degree for all citizens, but especially for those most in need... The limitation, or containment, of economic and other forms of inequality... A key role in sustaining these institutions is played by the 'social partners', the unions and other agencies promoting workers' rights. Each trait has to go along with expanding overall economic prosperity and job creation.” (p. 1)

More recently, however, this model is "under great strain, or even failing. The demise of Keynesianism in the West, and the collapse of Soviet Communism, were brought about by much the same trends - intensifying globalisation, the rise of a world-wide information order, the 
shrinking of manufacturing (and its transfer to less developed countries), coupled with the rise of new forms of individualism and consumer power. These are not changes that came and went; their impact continues today.... [Problems] do not just stem from changes happening in the global environment. Some of the core difficulties are internal, or at most only loosely connected with wider transformations in the wider world. They include primarily demographic changes, especially the ageing population, the associated issue of pensions, and the sharp decline in birth-rates; changes in family structure, with many more one-parent families than before, and more women and children living in poverty; and high levels of unemployment coming in some part from unreformed labour markets." (ibid.)

A degree of consensus has developed (e.g. Dostal (2005), Sapir (2005), European Commission (2006), Giddens (2005)) that some countries - particularly the Nordic and Anglo-Saxon ones - have been able to design, implement and sustain social policy changes that have provided a relatively successful answer to the challenges of globalisation and demography. The key continental economies - Germany, France and Italy in particular - have generally been unable to do so though Germany has witnessed some ambitious policy steps. The problem is not so much in different preferences of the policy-makers in these countries, but their inability to push through and politically sustain the needed reforms. Attempts by governments to do so - e.g. French government under Juppé, Italian government under Berlusconi - ended either in political disaster and retreat due to electoral opposition or only a very limited change.

Consequently, the issue of political economy has emerged as the key to a set of comprehensive social policy reforms. The contrasting experience of political economy of such reforms in Ireland, the UK or Finland on one hand and France, Germany, Belgium or Italy on the other is a frequent basis for analysis. What is usually ignored, despite more than 2 years since enlargement, is the experience of the new member states of the EU.

Among these member states, Slovakia is a particularly instructive example of a government able to introduce both radical and comprehensive package of social policy reforms, which has proven to be a policy success in terms of its outcomes and has also proven to be politically sustainable in the sense that a change of government has not led to major changes in the package despite pre-election rhetoric to the contrary. It is therefore the focus of our paper.

The experience of old member states shows that even implementation of significant shifts in social policy does not lead to convergence. Rather, both the so-called liberal-residual and socialdemocratic models managed to change within their quite distinct paradigms. The paper therefore also explores, using not only Slovak experience, whether a distinct paradigm can now be identified as emerging among some new member states.

\section{Social policy reform in Slovakia}

In 1998, a broad coalition of pro-democracy and pro-Western forces won the parliamentary election in Slovakia and unseated the government of Vladimír Mečiar, a populist with an authoritarian bent who had stopped structural reforms and alienated the West. In the 2002 election, the centre-left elements of this coalition lost their parliamentary representation, but the centre-right was able to achieve re-election on its own and governed for another four years until 2006. Both governments were headed by Mikuláš Dzurinda, but it was the second one which became well-known for its bold package of reforms, particularly in the social and fiscal area. The purpose of this section is to describe the policy climate underpinning the reforms and to describe briefly their content. 
The government decided to implement a comprehensive social policy reform in a particular policy climate, which can be best captured by selected quotes from its two key strategic documents, approved by the government in April 2003:

- Strategy to increase employment through reform of social policy and labour market (Employment strategy)

- Pension reform strategy

The Employment strategy stated: "Slovakia and its citizens have, for several years, considered the issue of unemployment and poverty as the most important. Families without anyone working are most likely to fall into poverty trap than can capture them for more than one generation.... To create jobs and decrease poverty, economic growth is not a sufficient condition... Incentives posed by social policy and flexibility of the labour market are also important... The labour market in Slovakia currently suffers from a variety of serious problems contributing to high unemployment and low employment... rigidity of the labour market, extremely high labour taxation... a poverty trap posed by the current social policy.... Active labour market policies as currently implemented have questionable efficiency and effectiveness... and the public agencies in this area are organised to serve needs of the administration, not of clients and the labour market... The objective of the strategy is to create a system which motivates individuals of working to find and retain employment and be active in resolving his/her social problems... Employment growth is the best anti-poverty device... Consequently, the social policy will achieve a situation where work pays more than absence of work and socially desirable activity pays more than the lack of it." (MoLSAF (2003a), p. 1)

The Pension reform strategy stated: "The main problem of the current system for funding pensions in Slovakia is the domination of the public pay-as-you-go pillar. This system is unsustainable in its current form if it is to fulfil its current paradigm of providing adequate income replacement in the case of old-age, long-term incapability to work or loss of the breadwinner. The unsustainability is caused not only by unfavourable demographic development, expectation of higher migration in the future as part of the EU, but also by the lack of property rights in the pension system and weak incentives to participate in the formal economy and thus contribute to the pension system... These are the reasons for a far-reaching reform of the current pension system including establishment of a compulsory old-age savings scheme." (MoLSAF (2003b), p. 1)

Based on these two strategic documents, a package of legislation was prepared during the first half of 2003, which was approved by the parliament between September 2003 and January 2004, with most of the measures coming into effect in January or February 2004. The package contained new legislation:

1. Concerning welfare and labour taxation

- reform of the minimum income guarantee scheme

- reform of the income tax and social security contributions (including reform of unemployment insurance and sickness benefit)

- reform of the system of financial support for families with children

2. Concerning labour market policy

- reform of the Labour code and labour market institutions (collective bargaining)

- reform of the active labour market policy

- reform of the administrative arrangements in the area of employment and social policy 


\section{Concerning pensions}

- restructuring of the $1^{\text {st }}$ (pay-as-you-go) pension pillar

- introduction of the $2^{\text {nd }}$ (funded) pension pillar

The reform of the welfare and labour taxation contained the following key measures: ${ }^{1}$

- Replacing the pre-existing two categories of social assistance beneficiaries with a single entitlement structure based on current, as opposed to past, individual labour market status and search

- Reducing the minimum social assistance benefit for a single adult to an amount below the subsistence minimum and weakening the link between family size and benefit level

- Introducing a number of new benefits for the working poor, available to families in which the adults are either working or participating in active labour market programs (ALMPs) and expanding the entitlement to social assistance benefits to the first 6 months of employment

- Providing subsidies to municipalities (and other stakeholders) for organizing training and targeted employment opportunities for the LTU ("activation programs")

- Replacing the previous income-related family benefits with a flat (not income-related) benefit per each child coupled with introduction of refundable tax credits for minor children

- Introducing social scholarship schemes for pupils attending primary and secondary education in addition to meal and schooling subsidies (also available to preschoolers)

- Increase in progressivity of the income tax system and significant cut in the tax wedge for low-income individuals due to:

$O$ doubling of untaxable personal allowance as well as the already mentioned refundable child tax credits

$O$ cuts in social security contributions by 3.25 percentage points thanks to entitlement reform in the sickness and unemployment insurance

- Reform of sickness benefits combining lower benefits for the first three days and shifting the responsibility for first 10 days to employers

- Unemployment benefit was made available only to those who contributed at least 3 of the last 4 years and is paid for the maximum of 6 months

Labour market policy reform contained:

- New Labour Code, designed to foster labour market flexibility, by inter alia:

O deregulation of working time including possibility of irregular work, significant increase in potential for overtime

O easing dismissal for misconduct or cyclical reasons

$O$ deregulation of temporary contracts

$O$ easing dismissal for part-time jobs

- Individual and targeted work with the unemployed (in-depth interviews, individual action plans for job-seekers, testing and assessment of personal characteristics, etc.)

- Reform of the active labour market policies to remove corruption and target it better at longterm unemployed and low-skilled by:

$O$ mandatory character of the ALM programs and the reimbursement of travel and child-care costs to job-seekers actively seeking employment and participating in ALM programs

O entitlement-based subsidies to employers hiring LTU and to LTU job-seekers planning to start a business

$O$ targeted interventions to regions with the highest incidence of unemployment

1 The paragraphs describing welfare and labour market reforms draw heavily on World Bank (2005) 
- Increase in the real value of the minimum wage

- Liberalisation of work for old-age and disability pensioners to work without the loss of pensions

- The reform of the administration of welfare systems, designed to merge the social agenda with the labour market policies in the regional offices, saving 1000 staff as well as providing better services for the majority of the unemployed who are on social benefits

- Introducing Social Development Fund (a microgrant community development program) as a way of helping poor communities recover economically and reduce poverty in a sustainable way.

Pension system reform contained:

- A rise of statutory retirement age from initial 60 years for men and 53-57 for women (depending on the number of children) to 62 years for both genders (with plans to increase it to 65 in the next decade). This will be done gradually at the rate of 9 months per year

- in the first pillar, the reform created a tight link between the amount of contributions and pension benefits. Solidarity in the system was restricted to support of individuals who are poor via social assistance

- Earlier retirement is possible if the pension benefit reaches at least $120 \%$ of the subsistence minimum. Moreover, it is penalised by pension reduction by $6 \%$ per year

- Those who postpone their retirement receive a bonus of $6 \%$ per year to their first-pillar pension

- The second pillar was set up by the Law on Old-Age Pension Savings which came into force in January 2005. All citizens in productive age had to decide within one and half years (January 2005 - June 2006) whether to begin saving on their own pension accounts or to stay in the reformed PAYG pillar. Once in the second pillar, they can not opt out. Saving in the fully funded pillar will be compulsory for the newcomers on the labor market.

- The pillar will be financed by pension contributions of $9 \%$ of the gross wage and which is the same in the first pillar. The pensioner entering the system will receive $50 \%$ of the firstpillar pension and what he/she manages to save in the second pillar

The reforms were followed by a significant improvement in indicators measuring key policy objectives.

Employment rate increased from $56.7 \%$ in the second quarter of 2004 to $59.6 \%$ in the second quarter of 2006, an increase of 3 percentage points after stagnating for several years. Unemployment decreased from $18.5 \%$ in the second quarter of 2004 to $13.5 \%$ in the second quarter of 2006, a decrease of 5 percentage points, also after stagnating for several years.

There are no trustworthy statistics comparing poverty before and after the reforms. Nonetheless, there is enough data to draw some conclusions. The Statistical Office of Slovakia conducted its first Survey of Income and Living Conditions (EU SILC) in 2005 to reflect the situation in 2004, after the implementation of reforms. This was the first poverty survey in Slovakia which was of sufficient quality to produce internationally comparable results. According to the survey, $13.3 \%$ of people in Slovakia were in risk of poverty, i.e. had income below $60 \%$ of the median income. The Gini coefficient reached 26.1 (Olexa and Haluška (2006)). These results place Slovakia in the less unequal half among the EU countries and show that the introduction of reforms was not accompanied by dramatic inequalities.

Simultaneously, the World Bank conducted simulations of the impact of reforms on poverty. According to its results, static poverty essentially did not change despite significant cuts in transfers 
because of better targeting. At the same time, the rapid employment growth is likely to significantly decrease poverty (WB (2005)).

The pension reform contributed significantly to improvement in the long-term fiscal sustainability (see below). It was also successful politically in the sense that 1.4 million individuals out of 2.6 million economically active chose to switch to the new two-pillar system. These were nearly completely concentrated among those younger than 45 , so in this age group the decision to participate was overwhelming.

The consolidation of the public finance in Slovakia was remarkably swift. In 2002, the fiscal deficit was $7.7 \%$ of GDP. By 2004, it dropped to 3\% of GDP. This improvement was not influenced by pension reform as its effect is mainly long-term. However savings from other social expenditures based on reforms described above (poverty, national funding for active labour market policies, family benefits, disability integration) significantly contributed to the consolidation. The Ministry of Labour, Social Affairs and Family estimated that the reforms cut such expenditures from 3.5\% of GDP in 2003 to expected 2.1\% of GDP in 2007. (Inštitút sociálnej politiky MPSVaR SR (2005)) In the long run, the pension reform meant that pension costs will increase by only $0.4 \%$ of GDP by 2055, instead of $6.4 \%$ without the reform (Inštitút finančnej politiky MF SR (2005))

\section{Designing, implementing and sustaining the reform package}

The following section is divided into three parts. Firstly, we discuss why the comprehensive social reform did not happen under the first Dzurinda government. The second part looks at factors enabling his second government to design and implement the reform package. The final section looks at the steps government took in the management of reforms after they were legislated to ensure their political sustainability.

If one looks at government during the 1998-2006 period, they were headed by Mikulás Dzurinda and, in both governments, the prime minister Dzurinda and deputy prime minister Mikloš were the key players on the reform front, pushing for radical structural reforms. The logical question then is - why were the results on social policy fronts so different, depending on the composition of the government. The first Dzurinda government (Dzurinda I) found it possible though difficult to achieve breakthroughs on the following fronts: enterprise restructuring and far-reaching privatisation, a new regulatory framework for energy and utilities, complete restructuring and privatisation of the banking sector, central bank independence and monetary policy, independence of the judiciary and decentralisation of public administration. However, it was not equally successful in implementing reforms in the areas of social policy. This was not for lack of trying. Many changes were passed, but they were often half-hearted and altogether of limited effectiveness.

The reason was simple: while the Prime Minister and the Deputy Prime Minister were committed to in-depth reforms on all fronts, this was not necessarily true to the same extent for many individual ministers and their civil servants. The top pro-reform oriented political leaders found that there were limits to the intervention from the very top. They had a view on how real pension or education reform should look like, but found it impossible, for political and capacity reasons, to make these views into an approved reform without active support of the relevant sectoral minister, particularly the Minister of Labour, Social Affairs and Family in Dzurinda I - Peter Magvaši..

This is not a Slovak idiosyncrasy. The World Bank research indicates that there is indeed a difference between the so-called first-generation and second-generation reforms. The firstgeneration reforms are those that can be devised, pushed through and implemented by a relatively 
small group of people from the top echelons of the government. Whether it is price or foreign trade liberalisation, central bank and fiscal management reform, tax reform or privatisation, the government capacity needed for their success is not large and the implementation takes a short time, after which the matters can be left largely to themselves.

None of this is true for the second-generation reforms, prominent among which are social programs. First of all, the reforms are not a one-time event, but a continuous process that needs to be managed and can be easily led astray. Their eventual success involves many more people in design, approval and implementation. The public is also more directly involved and has much more forceful views that need to be taken into account. Their technical complexity is usually higher and their success depends less (though it still does) on the quality of "big ideas" behind the reforms and more on quality of implementation and policy learning. That is why the commitment to the reform of top officials in the sectoral ministries is crucial. Without it, things will not move forward even if the very top political leaders support change, as was the case in Slovakia under Dzurinda I.However, the environment changed dramatically with the second Dzurinda government and there were several reasons enabling the government to move rapidly and radically on the social policy front.

The key factor that made it possible to implement and politically sustain such a comprehensive and, in many of its aspects unpopular, reform package was the electoral support for change and the moral bankruptcy of the old system. The personal experience and expectation of many aspects of social policy were unfavourable for an overwhelming majority of the population, be it in healthcare or pensions. Particularly in the area of pensions, there was a very low level of trust in the ability of the public system to provide adequate pension for the current cohort of young and middle-aged individuals. This is not unique to Slovakia, but is a feature of many, if not most postcommunist countries. ${ }^{2}$ In the sphere of employment, Slovakia witnessed a very weak job performance from 1997 to 2001, when medium to high economic growth was accompanied by low or even negative employment growth and low economic growth was accompanied by significantly negative employment growth. Unemployment was, together with Poland, the highest among existing or acceding EU members. The social assistance remained, despite some changes, similar in its philosophy since the introduction of economic reforms, and after approximately 10 years it was possible to observe that it was partially responsible for the culture of dependency and long-term unemployment.

Paradoxically, even the conflict between reformers and conservatives in the Dzurinda I government contributed to the reform environment, by increasing frustration among the policy community and part of the electorate - changes that seemed so close to happening slipped out of grasp, whetting the appetite for "real" reform.

Accidental developments also contributed to this politically and electorally supportive environment for reform. For example, Slovakia approved a new Labour Code in 2001 to replace one passed during 1960s and comply with the EU accession requirements. After its passage, it became clear that the new Code was rigid to the point where it threatened serious damage to the economy. Even though the Code was immediately amended to resolve the most glaring problems, the debate surrounding the issue set the stage for a much more thorough liberalisation later.

2 There is also nice anecdotal evidence in the form of a film created for ING, a Dutch banking and insurance group. In this short film, people in various European countries are asked about their views of the pension system. Participants from the postcommunist countries express nearly uniform lack of trust in the ability of the public pension system to provide for them. 
The second factor was that much of the learning and policy debate necessary to produce a comprehensive reform already occurred during the previous Dzurinda I government. While the precarious political balance between the left and the right prevented that government from enacting the more controversial aspects of social policy reform, it was, for the more liberal elements in the government, a test run during which they honed the policy ideas as well as the political rhetoric. This was crucial because it enabled the government to fully utilise a brief window of opportunity to draft and pass the necessary legislation without dithering and extensive internal debate.

Another factor that made it possible for the government to smoothly enact their policies was an absence of a coherent alternative policy package. Since there was strong popular pressure for reform, having essentially a monopoly on these reform policies meant an effective monopoly on policy (Mikloš et al. (2005), p. 10).

The fact that most of the media and policy community shared the view of the reforms reinforced these tendencies and contributed to the overall supportive environment for change. This of course does not mean that government policies were, in general, supported by the media and policy community. On the contrary, many government policies were subject to ferocious criticism. However, the essential reform paradigm was shared between the policy-making and policyreflecting communities. The best proof of that is the reform index composed by a group of nongovernmental commentators, ranging from journalists, bank analysts to think tank analysts (HESO).

The social policy reforms had the following rating:

Table 1: Social policy reforms rating by the policy community in Slovakia, 2003-2004

\begin{tabular}{|l|l|l|}
\hline Policy measures & Ranking among 114 measures ranked & Average score (-300 to 300) \\
\hline Labour Code reform & 4 & 157.2 \\
\hline Tax reform & 6 & 142.6 \\
\hline $1^{\text {st }}$ pillar reform & 7 & 133.8 \\
\hline $2^{\text {nd }}$ pillar reform & 14 & 112.3 \\
\hline Employment policy reform & 21 & 96.6 \\
\hline Social assistance reform & 33 & 81.2 \\
\hline Sickness benefit reform & 48 & 63.3 \\
\hline $\begin{array}{l}\text { Institutional reform in the social area } \\
\text { Child benefit reform }\end{array}$ & 61 & 49.6 \\
\hline Average & 80 & 33.2 \\
\hline
\end{tabular}

Source: Zachar (2004)

In other words, the key social policy reforms had the average ranking of 30 and an average evaluation of 90.6, far above the median for policy measures evaluated during this period.

Additionally, the government contributed to the enabling environment in several important ways.

First of all, it focused on utilising the window of opportunity for the reforms. The window itself lasted less than 15 months. The last major reform proposals that were politically costly or controversial passed in the parliament in January 2004. Already in February 2004, the parliament rejected a government proposal to introduce fees in higher education and, in the remaining two and a half years, the parliament refrained from approving such proposals. In the area of social policy, all the government key legislative priorities were drafted between January and July 2003, approved by 
the government by September 2003 and approved by the parliament by January 2004. This was the case even though the policy range and technical complexities were very high, but there was an overwhelming focus on the window of opportunity.

Secondly, most of the reforms - particularly those that won popular acceptance - focused not on parametric changes of existing systems, but rather on the introduction of a new paradigm and accompanying new social covenant. The new paradigm of "work must pay" and more individual freedom accompanied by higher individual responsibility contained a consistent message that was reflected in most policy measures. The other lesson is that a comprehensive reform can be acceptable even if it contains some fairly unpopular elements. Pension reform is such an example containing rapid increases in pension age, particularly for women, together with the introduction of a popular funded pillar and the possibility of a higher pension for those working longer and earning more - with a majority support for the whole package.

Thirdly, the government was able to react rapidly to unfolding problems and correct some of the problems accompanying introduction of the reforms. For example, when the implementation of the new system of social assistance was met by violent protests by some of the people affected, the government immediately passed a variety of measures designed not only to take the sting politically out of the protest, but also to remedy some of the shortcomings of the reform that became obvious with its implementation. There measures, rather than being stop-gap, proved to be among both the most popular, durable and praised by experts - e.g. the introduction of social scholarships, free meals for poor children.

\section{Sustainability of the reforms}

Sustainability of the reforms has two dimensions: financial and political. Financial sustainability was generally (though not universally) an issue with the Slovak social policy reforms because they were designed precisely to contribute both to the short- and long-term sustainability of public finance. For this reason and also because of the focus of this paper, we will concentrate on the political sustainability of the reforms.

There is no precise formula to calculate political sustainability of a given reform, but more the following criteria are met, the less likely it is that the reform will be overturned or amended substantially:

- it is electorally popular or at least accepted

- it is overwhelmingly accepted by the relevant policy and media community

- changes would be costly

- groups opposed to it are not well organised or dedicated to this goal

In Slovakia, polling conducted during late 2004 and early 2005 - i.e. after the reforms have been in action for nearly a year, but before the parliamentary elections - show that while there was a split in the view of the reforms as a whole (which applied to the social policy reforms as well), there was an overwhelming majority supporting their further modification ("improvement") rather than their abolition or return to the status quo ex ante. According to the polling, $46 \%$ of voters thought the country was going in the right direction, while $44 \%$ thought the opposite. Among likely voters, the reforms were approved of by $43 \%$, with $40 \%$ opposing. $72 \%$ of voters agreed with the view that reforms need to be improved and only $12 \%$ thought they should be abolished. (Rosner (2005))

Within this general view, there were highly divergent views of individual reforms. In the area of 
social policy, these can be roughly divided into two groups (ibid.):

- Popular packages: reform of financial support for families and pension reform. $24 \%$ more people supported the reform of support for families than opposed it and 13\% more people supported the pension reform than opposed it. These two were among the three reforms viewed most favourably by the public

- Balanced packages: labour market and social assistance reform, with favourability margins of +2 and -7 . (To illustrate, the most negatively perceived reform at the time, proposal to introduced fees at universities, had a -41 rating.)

In the following elections in June 2006, the government was not returned to power and previously opposition parties formed a new government. This however does not seem to follow directly from the reforms, but to other factors - coalition disagreements and break-up, political scandals etc. In the spring 2005, one year after the reforms were implemented, the electorate was balanced about the reforms, with the picture gradually worsening during the rest of 2005 and early 2006, indicating that it was not the reforms themselves that were the crux of the problem. Additionally, the key social reforms were generally seen as positive or neutral, unlike the healthcare or education reforms.

While it is yet to soon for definitive evaluation of the policy intentions of the new government, there are strong indications that there will not be a rupture in the area of social policy, again unlike in the health and education policy. The only major change the new government committed itself to is amendment to the Labour Code to rectify what it considers its excessively liberal tilt. Senior government figures also publicly announced that they are considering reduction in the share of the contributions going to the second pillar from $9 \%$ to $6 \%$ of the wage, but this has not been decided yet and is a subject of considerable controversy within the government itself. Otherwise, the announced changes are of a fairly nature.

\section{Towards a new social policy paradigm}

In May 2004, eight postcommunist countries of Central and Eastern Europe became members of the European Union. It is worth asking whether their social policy follows one of the traditional paradigms in the rest of Europe (following Gosta-Esping (1990) - residual-liberal, socialdemocratic or conservative-corporatist) or, after a tumultuous transition, is converging towards a new paradigm?

When one examines defining features of social policy in the sample, it quickly becomes clear that even though they are still subject to dynamic political and policy change, the eight countries are now close to one of the paradigms, but not all to the same one. Instead, they can be divided into two groups - see Table 2. While none of the countries fits its group perfectly, the distinctions between the two are surprisingly strong given their shared past.

Table 2: Social policy indicators in new member states - a new paradigm?

\begin{tabular}{|c|c|c|c|c|c|c|c|c|}
\hline & \begin{tabular}{|l|} 
Public \\
expenditure/ \\
GDP
\end{tabular} & $\begin{array}{l}\text { Social } \\
\text { benefits/GDP }\end{array}$ & $\begin{array}{l}\text { Employment } \\
\text { rate }\end{array}$ & $\begin{array}{l}\text { Employment } \\
\text { growth }\end{array}$ & $\begin{array}{l}\text { Unemployme } \\
\text { nt trap }\end{array}$ & \begin{tabular}{|l} 
Minimum \\
wage/average \\
wage
\end{tabular} & Inequality & $\begin{array}{l}\text { ALMP } \\
\text { expenditure }\end{array}$ \\
\hline $\begin{array}{l}\text { EU } \\
\text { countries) }\end{array}$ & 47.2 & 15.9 & 63.8 & 0.6 & 77.7 & n.a & 4.6 & n.a. \\
\hline $\begin{array}{l}\text { EU } \\
\text { countries) }\end{array}$ & 47.4 & 16 & 65.2 & 0.6 & 78.3 & n.a & 4.6 & 0.64 \\
\hline
\end{tabular}




\begin{tabular}{|l|l|ll|l|l|l|l|l} 
Czech Republic & 44.1 & 11.5 & 64.8 & 0.5 & 65 & 36 & 3.4 & 0.13 \\
\hline Hungary & 49.9 & 14.5 & 56.9 & 0.7 & 66 & 38 & 3.3 & 0.21 \\
\hline Poland & 43.4 & 15.7 & 52.8 & 0.9 & 83 & 36 & 5 & n.a \\
Slovenia & 47.2 & 16.3 & 66 & 0.6 & 80.5 & 42.25 & 3.1 & n.a \\
\hline Average & $\mathbf{4 6 . 2}$ & $\mathbf{1 4 . 5}$ & $\mathbf{6 0 . 1}$ & $\mathbf{0 . 7}$ & $\mathbf{7 3 . 6}$ & $\mathbf{3 8 . 1}$ & $\mathbf{3 . 8}$ & $\mathbf{0 . 1 7}$ \\
\hline & & & & & & & & \\
\hline Estonia & 33.2 & 9.2 & 64.4 & 1.1 & 50.4 & 31.25 & 5.9 & 0.04 \\
\hline Latvia & 36 & 8.8 & 63.3 & 1.2 & 87.1 & 37 & 6.1 & 0.09 \\
\hline Lithuania & 33.6 & 9 & 62.6 & 2.5 & 48.8 & 41.5 & 4.5 & 0.15 \\
\hline Slovakia & 37.1 & 10.8 & 57.7 & 1.6 & 43 & 41 & 5.4 & 0.07 \\
\hline Average & $\mathbf{3 5}$ & $\mathbf{9 . 5}$ & $\mathbf{6 2}$ & $\mathbf{1 . 6}$ & $\mathbf{5 7 . 3}$ & $\mathbf{3 7 . 7}$ & $\mathbf{5 . 5}$ & $\mathbf{0 . 0 9}$ \\
\hline SOurce: Eur. & & & & & & & & \\
\hline
\end{tabular}

Source: Eurostat, Eiro

Note: 2005 unless otherwise noted; employment growth 2003-2005 average; unemployment trap 2004; minimum wage 2001-2004 average; inequality 2003; ALMP 2004 (Latvia 2003)

The first group, composed of the Czech Republic, Hungary, Poland and Slovenia, has converged to the traditional continental model of the welfare state, associated with the conservative-corporatist model. The overall public expenditure is as high as in the rest of the EU and so is the social expenditure, based primarily on the social insurance model (though Hungary and Poland introduced compulsory funded pension pillars). Social protection and equality are relatively high, but accompanied by work incentive problems. Correspondingly, even though employment levels differ due to varying initial conditions, the employment rate is lower than in the EU25 and the employment growth is as slow as in the EU as a whole.

On the other hand, the three Baltic republics (Estonia, Latvia and Lithuania), together with Slovakia, present quite a different picture, much closer to the liberal-residual paradigm. The public expenditure is much lower than the EU average, which also applies to the social expenditure. While the social insurance also plays a crucial role, there is more emphasis on means-testing and/or universalism as well as a strong private pension provision. There is a strong emphasis on employment and employment growth as the key social policy objective, with stingy social protection levels and low unemployment traps. The countries involved pay a higher-than-average price in heightened inequality.

Both groups share relatively rigid labour markets de iure, but quite liberal in practice (due to capacity constraint in enforcement and relatively weak unions), average to high minimum wage and low active labour market policy expenditure.

It is not surprising that countries in the orbit of Germany and Austria are converging towards similar types of conservative-corporatist social policies. What is more interesting is that the Baltic states are so close to the liberal-residual ideal type instead of the social democratic one of their Nordic neighbours. The case of Slovakia also presents an intriguing question of a country moving out of the orbit dictated by its heritage and into a new one. However, it is too soon to posit this development as definitive and only after a decade or so can one truly confirm a paradigm shift.

\section{Conclusion}


The paper used the example of Slovakia, which has been able to introduce a comprehensive social policy reform to study the political economy of such changes and what has enabled the Slovak government to successfully introduce them.

It found that the radical policy shift was enabled by a combination of electoral support for change, supportive media and elite environment and a government able and determined to utilise the window of opportunity. These factors have also been crucial in ensuring political sustainability of the reforms. Thus, there was an element of luck and coincidence, but their role was minor.

As a result of these changes, Slovakia has now joined the three Baltic countries in a group with social policies close to the liberal-residual model usually found in the Anglo-Saxon countries, while the rest of the postcommunist Member States of the EU have converged to the conservativecorporatist model followed by most of the continental EU states. None has chosen the Nordic social-democratic model. 


\section{References}

Český rozhlas (2004) Gerhard Schroeder in Prague: radical social policy reform is needed across Europe, radio report by David Vaughan, Gerald Schubert, October 5, 2004

Dostal, M . (2005) Labour Market and Social Policy Reform in the EU: EU (and European!) Experiences for Asia, Presentation on Friday 26 August 2005 at the Chinese University of Hong Kong, Hong Kong

European Commission (2006) The Long-Term Sustainability of Public Finances in the European Union, European Economy n ${ }^{\circ}$ 4/2006, European Commission, Brussels

Giddens, A. (2005) The World Does not Owe us a Living! Progessive Politics vol. 4.3: Social Europe's Renaissance?, Policy Network, London

Esping-Anderson, G. (1990) The Three Worlds of Welfare Capitalism, Princeton University Press, Princeton

Inštitút finančnej politiky Ministerstva financií SR (2005) Dlhodobá udržatel'nost' verejných financií ako základný ciel’ fiškálnej politiky, October 2005, Ekonomická analýza No. 9

Mikloš, I. et al. (2005) Kniha reforiem: Ako si Slovensko získalo medzinárodné uznanie v ekonomickej oblasti, Ministerstvo financií SR, Bratislava

Inštitút sociálne politiky MPSVaR SR (2005) Konsolidácia verejných financií 2003-2006: príspevok sociálnej politiky, MPSVaR SR, Bratislava, internal presentation

MPSVaR SR (2003a) Stratégia podpory rastu zamestnanosti prostredníctvom zmien sociálneho systému a trhu práce, Ministry of Labour, Social Affairs and Family of the Slovak Republic, Bratislava

MPSVaR SR (2003b) Návrh koncepcie reformy dôchodkového zabezpečenia v SR, Ministry of Labour, Social Affairs and Family of the Slovak Republic, Bratislava

Olexa, M. and J. Haluška (2006) Súčasná ekonomická situácia v Slovenskej republike, Country paper, Global Policy Network, ww.gpn.org, accessed October 10, 2006

Rosner, J. (2005) Information about Slovak Reforms, Results of Public Opinion Survey, March 2005, Greenberg, Quinlan and Rosner Research, Washington, D.C.

Sapir, A. (2005) Globalisation and the Reform of European Social Models, Background document for the presentation at ECOFIN Informal Meeting in Manchester, 9 September 2005

World Bank (2005) The Quest for Equitable Growth: Living Standards Assessment: Slovak Republic, World Bank, Washington, D.C.

Zachar, D. (ed.) (2004) Reformy na Slovensku 2003-2004, Hodnotenie ekonomických a sociálnych opatrení, INEKO, Bratislava 